\title{
GRAN MARCHA NACIONAL POR LA PAZ Y LA SOLIDARIDAD EN COSTA RICA
}

Carlos Sandoval García

\author{
Recibido: 22/07/2019 - Aceptado: 29/08/2019
}

\section{Introducción}

El sábado 18 de agosto 2018, unas 500 personas se manifestaron en contra de la inmigración en Costa Rica. La policía detuvo a 44 de ellas, 38 eran costarricenses. La mayoría de los asistentes fueron hombres, muchos vestidos con la camiseta de la selección nacional de fútbol. Algunos exhibían símbolos nazis en sus cuerpos. "Queremos patadas" se coreaba en el Parque de La Merced.

¿Fueron estos eventos un "zafarrancho", como titularon algunos medios de comunicación? No. Lo ocurrido en el Parque de La Merced cruzó una línea muy peligrosa: las frases habituales que se leen en redes sociales, como "Fuera nicas", tomaron forma en una acción colectiva. Incluso se encontraron ocho bombas molotov, elaboradas con botellas de vidrio, combustible y una mecha, listas para ser empleadas. Armas blancas también fueron decomisadas.

Estas manifestaciones de xenofobia han estado presentes en sitios web y en redes sociales desde hace mucho tiempo. El ascenso de la ultra derecha en Estados Unidos y varios países de Europa ha envalentonado a quienes no solían manifestarse en espacios públicos.

Algunos perfiles de Facebook incluso toman prestado el nombre de movimientos que se han legitimado en los Estados Unidos y en países europeos. Es posible encontrar perfiles que se llaman, por ejemplo, "Alt Right costarricense", en el cual "alt" es la abreviatura de "alternative". "Alt Right" es uno de los movimientos que impulsaron y que celebran a Donald Trump.

Esta "derecha alternativa" se separa de movimientos más tradicionales, asociados al nacional socialismo y a la "pureza racial". Hoy la migración reemplaza a estos términos y se convierte en un referente que articula y aglutina. A menudo, además, las referencias a xenofobia y a la homofobia se intercalan en las publicaciones. 
Frente a este panorama, el Colectivo de Bienestar y Migraciones, integrado por alrededor de 12 organizaciones que trabajan con personas migrantes y refugiadas, convocamos a una marcha por la paz y la solidaridad el día sábado 25 de agosto. Unas 4000 personas salimos de la Universidad de Costa Rica y del Parque de La Merced y llegamos a la Plaza de la Democracia.

El odio y el miedo le temen a la alegría, por eso esta marcha se vistió de fiesta, música y baile. Zancos, mantas, pasacalles, comparsas, cantautores le dieron vida a la paz y a la solidaridad.

Patricia Mora, profesora universitaria, cofundadora del partido Frente Amplio, exdiputada de la República y en la actualidad Ministra de Condición de la Mujer, compartió unas palabras en este esfuerzo y encuentro colectivo. Las transcribimos a continuación.

\section{Discurso de la señora Patricia Mora Castellanos}

La nación costarricense ha sido constituida, a lo largo del tiempo, por la convivencia, el trabajo, las tradiciones y la cultura de diversos grupos, en particular de indigenas, europeos, mestizos, negros, asiáticos y latinoamericanos. Todos estos grupos han sido inmigrantes, es decir, todos han sufrido desplazamientos, cambios en sus modos de vida, en sus empleos, en los lugares en los que residen. Ha sido un proceso rico, largo, complejo, a menudo doloroso, en el que cada comunidad ha contribuido, desde su singularidad y su diferencia, a dar forma a lo que es la Costa Rica pluriétnica y multicultural que reconoce el artículo 1 de nuestra Constitución desde apenas el año 2015. El mito de una Costa Rica racialmente pura, homogénea y blanca es eso. Un mito. Una fábula. Una representación falsa que ha pretendido borrar, invisibilizar y a menudo denigrar a los grupos, las comunidades que no han calzado, en un momento o en otro, con ese relato dominante fundacional. Todos pertenecemos a Costa Rica. Todos y todas somos sus ciudadanos. Es peligroso e históricamente engañoso, falso, presumir que existe un grupo de habitantes que ha pertenecido a la nación desde tiempos primordiales y que por ello debe gozar de derechos y privilegios diferentes al resto.

Muchos medios de comunicación y discursos políticos oportunistas han contribuido a través de las décadas a reforzar una representación del nicaragüense como un otro amenazante, violento, pobre y de piel oscura que viene a contaminarnos, a abusar de nuestra hospitalidad, a delinquir, a robar, a violar. Este discurso que convierte al nicaragüense en parásito lo que permite, entre otras cosas, es invisibilizar las raíces de un problema más complejo: encubre la discriminación y la sobreexplotación que sufren los inmigrantes en las plantaciones de piña y banano, en la industria de la construcción, en los trabajos domésticos peor remunerados. Oculta, pues, que en su inmensa mayoría es una población económicamente activa, que contribuye a la riqueza nacional. Se les acusa igualmente de saturar los servicios públicos, de ser los responsables de la crisis y el deterioro que sufre la educación, la salud, la vivienda. Al culpabilizar al nica extranjero del 
deterioro constante de las condiciones de vida del pueblo costarricense, los gobiernos de turno y las clases dominantes han querido distraer la atención de la raíz más profunda de esos problemas. De los recortes constantes en la inversión pública, de la corrupción galopante en el ámbito público y en el privado, de la creciente desigualdad. El incremento de los privilegios de unos pocos ha aumentado la ansiedad de muchos. Esta ansiedad, y esto lo hemos visto una y otra vez en la historia, fácilmente se transforma en desconfianza, en odio al otro, al que está por debajo, al diferente, al que no es parte de un "nosotros" imaginario, idealizado, mitificado. Por estas razones es que cada vez que hay un brote de odio, de violencia racista, de xenofobia, debemos preguntarnos ¿Quién tiene interés en sembrar tensiones y guerra entre nuestra ciudadania?, ¿quién o qué grupo y para cuáles fines están llevando agua para su molino con esta declaratoria de "guerra" contra los hermanos y hermanas nicaragüenses?

Hace solo unos meses, circularon en la prensa internacional las abyectas imágenes de niños y niñas, casi todos centroamericanos, separados ilegalmente de sus familias, es decir, secuestrados por los servicios migratorios estadounidenses cuando intentaban atravesar la frontera entre ese país y México. Seres humanos, pequeños y pequeñas, tratados peor que a criminales cuyo único delito es el de jugarse la vida para encontrar mejores condiciones de vida que en sus países. Entre esas imágenes vergonzosas para la humanidad entera, una era particularmente desgarradora: la de un niño costarricense abandonado por su tío en el desierto de Arizona. Un lugar inhóspito en el que las temperaturas extremas ponen en riesgo la vida humana y sobre todo la de un pequeño solo y desvalido. Pienso aún en esa imagen intolerable. Un niño abandonado a su suerte, ¿por quién? Fundamentalmente por una política migratoria racista y criminal, por un mundo en el que la riqueza está cada día más concentrada en lugares geográficos, por sociedades que desprecian a sus ciudadanos y sobre todo a su niñez y un largo etcétera. Esa fotografía es un espejo en el que el sábado pasado muchos temimos reconocernos. Dejar que la indiferencia ante tales manifestaciones de odio xenófobo nos paralice, significa convertirnos en cómplices de un mundo que meta en cárceles a niños y niñas cuyo único delito es migrar y deja en la calle a criminales de toda ralea.

El primer derecho universal es también un deber: el de la fraternidad. La fraternidad exige que consideremos que la única verdadera patria es la humanidad entera.

Patricia Mora Castellanos

Ministra de Condición de la Mujer

Carlos Sandoval García. Costarricense, doctor en estudios culturales por la Universidad de Birmingham, Inglaterra. Se desempeña como profesor de grado y posgrado de la Escuela de Ciencias de la Comunicación Colectiva, y como investigador 
del Instituto de Investigaciones Sociales, ambos en la Universidad de Costa Rica. Coordina el Doctorado en Ciencias Sociales sobre América Central y participa en algunas iniciativas por la defensa de los derechos de personas migrantes.

Contacto: carlos.sandoval@ucr.ac.cr

ORCID: 0000-0002-7660-4375 